\title{
STRATEGI KOMUNIKASI BISNIS HIPMIKINDO DALAM MENSINERGIKAN SUMBERDAYA AKADEMISI DAN PELAKU UMKM
}

\author{
Misnan $^{1 *}$, Rezzi Nanda Barizki ${ }^{2}$ \\ 1,2Institut Bisnis dan Informatika Kosgoro 1957 Jakarta, Indonesia \\ *cakmisnankece@gmail.com
}

Submitted: 09-11-2021, Revision: 08-12-2021, Accepted: 29-12-2021

\begin{abstract}
The synergy of MSME actors and academics is a new thing in facing the challenges of digitalization. HIPMIKINDO has a strategic positioning between the two parties. The purpose of this research is to know the business communication strategy of HIPMIKINDO in synergizing the resources of academics and SMEs. Through qualitative approach and descriptive method, the result obtained is the form of the terminology concepts of the business communication strategy of pull, push and pass. In the push business communication strategy, HIPMIKINDO implements the managing business disruption message, which is exist a threat to MSME business continuity, so that the context of entrepreneurship requires transformative acceleration towards technopreneurship. At the push step, the motivation of the business cycle without innovation and creativity must be faced with resource competencies. This can be overcome by the presence of the role of academics in accelerating the development of MSME capacity building. Furthermore, the pass is implemented with the establishment of an entrepreneur center, which becomes a communication node for academics, MSMEs as well as across parties and institutions that want to play more active in synergies.
\end{abstract}

Keywords: business communication strategy; hipmikindo; msme; academics

\begin{abstract}
Abstrak
Sinergi pelaku UMKM dan akademisi merupakan hal baru dalam menghadapi tantangan digitalisasi. HIPMIKINDO memiliki positioning strategis di antara dua pihak. Tujuan penelitian adalah untuk mengetahui strategi komunikasi bisnis HIPMIKINDO dalam mensinergikan sumberdaya akademisi dan pelaku UMKM. Melalui pendekatan kualitatif dan metode deskriptif, didapatkan hasil berupa konsepkonsep peristilahan strategi komunikasi bisnis pull, push dan pass. Strategi komunikasi bisnis push, diimplementasikan dengan pengelolaan pesan disrupsi bisnis, yang menjadi ancaman kelangsungan bisnis UMKM, sehingga konteks entrepreneurship dibutuhkan akselerasi transformatif ke arah technopreneurship. Pada tahapan push, motivasi siklus bisnis tanpa inovasi dan kreativitas harus dihadapi dengan kompetensi sumberdaya. Hal ini dapat diatasi dengan hadirnya peran akademisi dalam mempercepat pengembangan capacity building UMKM. Selanjutnya pass, terimplementasi dengan didirikannya entrepreneur center, yang menjadi simpul komunikasi akademisi, UMKM serta lintas pihak dan institusi yang ingin berperan lebih aktif dalam sinergi.
\end{abstract}

Kata kunci: strategi komunikasi bisnis; hipmukindo; umkm; akademisi

\section{PENDAHULUAN}

Keberadaan

HIMPIKINDO

(Himpunan Pengusaha Mikro, Kecil dan Menengah Indonesia) sangat strategis. Tidak terbantahkan lagi jika dari berbagai isu ketahanan ekonomi Indonesia adalah ketahanan para pelaku UMKM (Usaha Mikro, Kecil dan Menengah). Pada awalnya penamaan secara umum, UMKM banyak dikenal sebagai perkumpulan pedagang kecil, tetapi karena adanya proses pembinaan dari arus atas dan arus bawah, yang pada awalnya kecil tentu bertambah kapasitasnya.

Berdasarkan dokumen AD - ART HIPMIKINDO, tertera bahwa masyarakat 
adil dan makmur berdasarkan Pancasila dan Undang-Undang Dasar Negara Republik Indonesia tahun 1945 harus diwujudkan melalui perekonomian nasional berdasarkan demokrasi ekonomi. Kemudian daripada itu, sesuai dengan amanat Tap. MPR-RI tahun 1998 tentang politik ekonomi dalam rangka demokrasi ekonomi, usaha mikro, kecil dan menengah perlu diberdayakan sebagai bagian integral ekonomi rakyat yang mempunyai kedudukan, peranan, dan potensi strategis dalam mewujudkan perekonomian nasional yang seimbang, berkembang dan keadilan bagi seluruh rakyat Indonesia.

Bahwa kemudian pemberdayaan UMKM (Usaha Mikro, Kecil, dan Menengah) harus terimplementasi secara menyeluruh, maksimal dan berkelanjutan melalui pengembangan iklim yang kondusif, kesempatan berusaha, dukungan, perlindungan, dan pengembangan usaha yang seluas-luasnya, sehingga mampu meningkatkan kedudukan dan peran serta potensi usaha mikro dan kecil. Hal ini demi mewujudkan pertumbuhan ekonomi, pemerataan dan peningkatan pendapatan rakyat, penciptaan lapangan kerja, dan pengentasan kemiskinan. Sehubungan dengan perkembangan lingkungan perekonomian yang semakin dinamis, kapitalisme yang terus menguat serta globalisasi yang bisa menghancurkan sistem perekonomian bangsa, ternyata pengusaha mikro dan kecil menjadi andalan stabilitas.

Adanya krisis ekonomi, akibat pasar bebas dan globalisasi, ternyata UMKM menjadi ketahanan ekonomi yang membanggakan. Untuk itu, pengusaha mikro dan kecil sangat perlu dilindungi. Realitas yang ada, para pengusaha mikro dan kecil belum terwadahi dalam sebuah perhimpunan khusus, sehingga wadah yang mampu menghimpunnya menjadi hal yang sangat mendesak, termasuk upaya paralel, membina dan memberdayakan (Phalipi, 2014).
Dari dokumen tersebut dapat dinyatakan bahwa pembinaan "arus atas" harus menjadi target perjuangan maksimal para pimpinan. Sebagai hasilnya tentu banyak kebijakan yang dihasilkan untuk mendorong UMKM terus terfasilitasi kebutuhannya. Beragam stimulus kemudian tersalurkan, baik dari sektor perbankan ataupun non perbankan. Adapun di arus bawah, terdapat banyak sekali aktivis, LSM, studi-studi, akademisi bahkan mahasiswa ataupun kelompok-kelompok di tingkat daerah yang mengakui dan ikut proaktif berperan dalam isu-isu kemajuan UMKM di Indonesia.

Gambaran ini secara umum sangat jelas, bahwa organisasi yang secara aktif memainkan peran dalam bingkai kemajuan UMKM, dengan berbagai konteksnya akan dipandang sangat positif dan strategis. Di celah inilah HIPMIKINDO berdiri. Dia tidak hanya mampu mengisi "ruang kosong" simpul komunikasi antara arus atas dan target terbawah, tetapi mampu mengintegrasikan simpul komunikasi yang tentunya sangat kompleks jika melihat demografi Indonesia yang sangat luas dan berwarna (Sitinah \& Sofiawati, 2021).

Dengan terbentuknya

HIPMIKINDO, para pelaku usaha mikro, kecil dan menengah (UMKM) di seluruh Indonesia, serta semua stakeholders terkait, dapat bersinergi bersama-sama, menuju terciptanya keadilan dan kesejahteraan. Demikian tagline HIPMIKINDO dalam melegitimasi organisasi. Tentunya, tagline ini tidak berlebihan, jika mengingat soko guru perekonomian Indonesia kini diakui secara terbuka, bahwa UMKM paling berkontribusi.

Sementara itu, positioning pemerintah dan UMKM seakan masih berada pada kutup oposisi biner. Sebagai komponen praktisi, para pelaku UMKM masih merasakan ada kesenjangan yang sangat berjarak, pemerintah seakan enggan membangun fasilitas infrastruktur dan suprastruktur yang langsung "membumi", 
terbukanya komunikasi bisnis antara pemerintah (birokrat) dan UMKM secara langsung. Oleh karena itu, para pelaku UMKM lebih banyak mengetahui program dan informasi fasilitas bisnis dari HIPMIKINDO. Seandainya jalur ini dapat diperpendek rantai organisasinya, harapan percepatan sangat dominan terwujud. Sudut pandang ini tentunya menghadapi tantangan yang tidak sederhana, misalnya dalam hal evaluasi dan pengawasan apalagi sisi kelayakan. Meskipun undangan seremonial dalam seminar dan workshop, yang memang pembicaranya berasal dari para pimpinan kementerian atau perbankan, yang memang sangat formal, sehingga berpotensi sangat teoritis dan belum bisa dipahami dengan mudah, tetapi program semacam ini sangat strategis dalam implementasi komunikasi yang informatif, edukatif dan inspiratif. Pada posisi ini eksistensi HIPMIKINDO memiliki peran yang besar untuk menjadi simpul komunikasi sekaligus simpul mediasi.

Perkembangan UMKM yang memasuki masa pandemi, peralihan dari pemasaran offline ke dunia digital, tidak semua UMKM siap dengan kompetensi yang serba baru tersebut. Optimasi penggunaan media sosial untuk meningkatkan pemasaran ternyata tidak mudah. Setelah melalui serangkaian program pelatihan, ternyata perubahan yang dirasakan para pengusaha di tingkat UMKM tidak signifikan. Pelatihan-pelatihan serupa hanya memberikan kelas-kelas tentatif tanpa bimbingan intensif yang terencana dan terjadwal. Namun demikian, aktivitas bisnis ini kemudian menjadi positioning strategis bagi HIPMIKINDO. Di antara UMKM dan pemerintah, HIPMIKINDO dapat merelasikan kegiatan pelatihan ke arah kampus. Hal ini tidak sulit mengingat orientasi kurikulum kampus yang banyak diarahkan pada bidang wirausaha mandiri. Hasilnya, HIPMIKINDO dapat menjadi center of needs dari pemerintah, UMKM ataupun akademisi (Gambar 1)

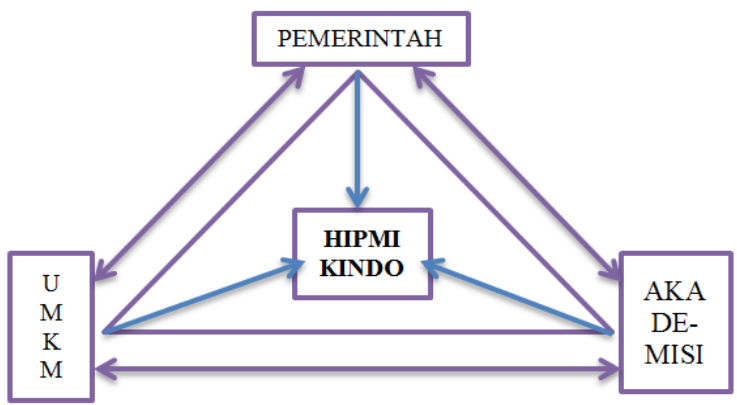

Gambar 1. Positioning HIPMIKINDO diadaptasi

dari Sukma \& Pranawukir (2020)

Di lain pihak, aktivitas bisnis HIPMIKINDO, antara lain penggalangan pelaku usaha kecil, pemasaran, pelayanan publik, dan program-program penyadaran masyarakat sudah menjadi fenomena komunikasi, atau lebih tepatnya komunikasi bisnis. Konteks komunikasi tidak hanya memberi informasi, tetapi juga membentuk citra, mempersuasi, dan mendidik masyarakat melalui program-program. Aspek-aspek identifikasi kebutuhan khalayak, strategi menyusun pesan, memilih media, menyebarluaskan dan mendekati target sasaran dikemas dalam perencanaan dan strategi komunikasi bisnis. Strategi ini sangat membantu para komunikator dalam memahami tugas-tugas yang diembannya, lebih kreatif dan lebih sigap dalam melihat peluang (Wijaya, 2015).

Strategi komunikasi bisnis dapat dilihat dari dinamika pola dan modelnya. Diantaranya model pull, selanjutnya model push, dilanjutkan dengan pass. Dalam hal UMKM, pull, misalnya dengan menampung semua aspirasi dan inspirasi para pelaku UMKM untuk dicarikan jalan solusinya, sedangkan push, strategi komunikasi perubahan budaya berjualan melalui pesan 5R: Ringkas, Rapi, Resik, Rawat dan Rajin. Hambatan komunikasi dalam implementasi strategi dapat meliputi aspek budaya, pendidikan dan personal. Sedangkan aspek pendukung adalah bidang operasional UMKM yang sudah melekat pada semua lapisan masyarakat sebagai penjual produk 
murah tradisional yang menjadi solusi hemat (Sukma \& Pranawukir, 2020).

Jadi, aspek teoritis dari strategi komunikasi bisnis dalam penelitian ini, peneliti mengadopsi strategi marketing public relations, yakni pull, push dan pass. A pull strategy, artinya menciptakan permintaan konsumen. A push strategy, artinya strategi mendorong produk melalui suatu saluran. A pass strategy diperlukan jika perkembangan lingkungan semakin kompleks, khususnya dibutuhkan strategi tertentu untuk menghadapi tantangan dan tuntutan bisnis yang sangat dinamis (Widuhung, 2021) (Murdaniati \& Widodo, 2018) (Sukma \& Pranawukir, 2020).

Sinergi dengan program

Kementerian Koperasi sangat dibutuhkan. Pengembangan kapasitas manajemen dan usaha koperasi belum optimal. Artinya, pemberian konsultasi, pelatihan dan pendampingan oleh para ahli (akademisi) menjadi prospek masa depan kemajuan UMKM (Kurniawati, 2021). Hal ini tentu menjadikan HIPMIKINDO memiliki eksistensi yang strategis secara vertikal dan horisontal.

Secara teoritis, komunikasi bisnis diperlukan dalam kegiatan bisnis dengan orientasi keuntungan. Dalam praktiknya, komunikasi bisnis cenderung menggunakan teknik dan strategi yang menguntungkan pemilik modal atau shareholder dan merugikan stakeholder. Kecenderungan itu dilakukan dengan memanipulasi bahkan "membohongi" pihak stakeholder demi kepentingan shareholder. Komunikasi bisnis etis sangat diharapkan untuk diterapkan agar semua pihak yang terlibat dalam kegiatan bisnis sama-sama menikmati keuntungan. Kehadiran HIPMIKINDO juga berkaitan dengan literasi bisnis semacam ini. Komunikasi bisnis yang etis adalah komunikasi bisnis yang mengikuti aturan moral dan norma moral yang ada, baik bersifat utilitarian, deontologis, keutamaan maupun yang berhubungan dengan hak dan keadilan. (Philipus, 2018) (Shansis \& Ratna, 2019)

Adapun pada sisi "internalisasi”, kerangka kerja HIPMIKINDO berkaitan dengan push daya adaptasi terhadap teknologi, yang dalam hal ini adalah teknologi/media digital. Dunia digital dengan segala kebaruannya telah membawa perubahan di segala bidang. Hal ini dipicu oleh munculnya teknologi internet. Berbagai sektor beradaptasi. Jika dua dasawarsa sebelumnya, dunia bisnis masih banyak menggunakan cara tradisional, kini dunia bisnis telah dominan "migrasi" menggunakan media digital. Sebagai contoh Tanifund adalah platform pendanaan keuangan yang berfokus pada pertanian, peternakan, dan perikanan. Hal menarik adalah adanya perbedaan besar antara era pertanian digital yang "memindahkan" lahan pertanian ke dunia digital. Hal ini sekaligus mengubah cara pandang tradisional yang menganggap pertanian merupakan pekerjaan berat, yang hanya dapat dilakukan di lahan terbuka (Mellyan, 2020).

HIPMIKINDO menyadari, bahwa daya saing UMKM sangat ditentukan oleh kecepatan adaptasi dari sistem konservatif kepada sistem moderatif. Pengelolaan konservatif membuat bisnis menjadi lambat dalam pertumbuhan (pasif), tidak sesuai dengan kebutuhan pasar yang terus berkembang. Dengan adanya moderasi, manajemen organisasi, tindakan pendelegasian, pengangkatan dan pemberian kepercayaan sangat efektif, karena mampu membangun kemandirian dan keterampilan kewirausahaan (Andriani, 2020).

Sebagai bagian integratif komunikasi bisnis, strategi tidak hanya dilakukan dalam konteks penawaran produk/jasa secara terbuka, tetapi juga dilakukan melalui aksi sosial. Dalam hal ini, keberadaan strategi komunikasi bisnis dan program tanggung jawab perusahaan sangat penting (Krisnayana, 2016). Programprogram CSR yang berkelanjutan dan menyentuh secara langsung terhadap aspek- 
aspek kehidupan masyarakat merupakan bagian yang tidak terpisahkan. Berbeda halnya dengan modal finansial yang dapat dihitung nilainya secara kuantitatif, modal sosial sebaliknya (Suyani et al., 2019). Inilah salah satu contoh implementatif dari teori pass strategy.

Pada penelitian ini juga digunakan kajian literatur dengan menampilkan penelitian sejenis terdahulu. Dalam hal ini peneliti melakukan seleksi dari topik strategi komunikasi bisnis digital, yang menjadi permasalahan kompetensi sumberdaya UMKM. Sisi MSDM para pelaku UMKM di tengah budaya digital inilah yang menjadi tantangan sinergis dengan dunia akademisi, untuk mengakselerasi kompetensi bisnis para pelaku UMKM.

Penelitian pertama oleh Afriaris dan Windartini, "Model Pengembangan Strategi Komunikasi Bisnis untuk Mencapai Tujuan Pemasaran pada Usaha Kecil Menengah (Studi Kasus pada Konsep Usaha Rumah Tangga Kerak Nasi)". Penelitian ini menggunakan metode penelitian deskriptif kualitatif dengan melakukan pengamatan langsung terhadap objek yang diteliti (paradigma post positivisme) serta teknik pengumpulan data berupa wawancara dan observasi. Hasil penelitian dapat disimpulkan bahwa: (1) Dalam tahapan attention dengan memperhatikan permintaan produk dari konsumen, hal ini berpengaruh positif terhadap kesan pertama bagi pembeli. (2) Pada tahapan interest dengan menanamkan kepercayaan kepada konsumen untuk mempermudah dan membuat keputusan. (3) Dalam tahap desire dengan meyakinkan konsumen melalui keunggulan dan penawaran harga khusus agar konsumen memiliki hasrat untuk membeli. (4) Dalam tahap action dengan memastikan konsumen yakin dan percaya terhadap kualitas produk sehingga pembelian produk merupakan keputusan yang tepat. (Afriaris \& Windartini, 2021)

Perbedaan penelitian Alfaris dan Windarti dengan penelitian ini adalah teori dan model yang digunakan. Penelitian Alfaris dan Windarti menggunakan AIDA (Attention, Interest, Desire, Action), sedangkan penelitian ini menggunakan model pull, push dan pass. Adapun persamaannya adalah metode, paradigma dan teknik pengumpulan data.

Penelitian kedua oleh Ningsih et al, "Strategi Komunikasi Bisnis Kewirausahaan Eco Pesantren Daarut Tauhid". Penelitian ini mengkaji proses penyampaian informasi, persuasi, dan evaluasi dalam komunikasi bisnis pada kewirausaha an Eco Pesantren Daarut Tauhid. Penelitian ini menggunakan metode studi kasus dengan pendekatan kualitatif. Teori yang digunakan difusi inovasi dan model AIDA yang berkaitan dengan attention (perhatian), interest (minat), desire (hasrat), dan action (tindakan). Penelitian ini juga menggunakan analisis SWOT (strength, weakness, opportunity, dan threat). Hasil penelitian menunjukkan bahwa penyampaian informasi dilakukan dengan keramahan, kesederhanaan, kesesuaian, dan keterhubungan. Proses persuasi diwarnai corak kebaikan dan kekuatan yang tercermin dalam karakter kedisiplinan, keberanian, kejujuran, keikhlasan, ketangguhan, dan ketawadhuan. Inovasi dalam kewirausahaan Eco Pesantren Daarut Tauhiid meliputi asrama bambu yang komunikatif, bagi hasil dalam sistem agrobisnis dan penitipan barang dagangan $\mathrm{d}$ alam warung kebersamaan. (Ningsih et al., 2018)

Perbedaan penelitian Ningsih et al dengan penelitian ini adalah model analisis yang digunakan. Ningsih et al menggunakan model AIDA dan analisis SWOT, sementara penelitian ini menggunakan model pull, push dan pass. Adapun persamaannya adalah pendekatan kualitatif.

Penelitian ketiga oleh Kurniawati, "Strategi Digital Marketing dan Komunikasi Bisnis untuk Enterpreneur Pemula di Indonesia". Latar belakang penelitian ini melihat perkembangan UMKM yang 
memasuki masa pandemi peralihan dari pemasaran offline ke dunia digital. Metode penelitian yang digunakan adalah kualitatif deskriptif dimana para pelaku UMKM/IKM mendapat pemaparan informasi melalui kelas berbayar sangat murah dan paparan informasi rutin terjadwal, dan teknik penulisan iklan yang praktis. Dengan upaya tersebut diharapkan kompetensi UMKM meningkat, apalagi telah dilakukan sinergi dengan program Kementerian Koperasi dan UMKM yang salah satu program unggulannya adalah pengembangan kapasitas manajemen dan usaha Koperasi. Dengan adanya pemberian konsultasi, pelatihan dan pendampingan oleh para ahli, dalam hal ini peneliti sebagai akademisi mampu menjembatani program tersebut guna turut berkontribusi dalam kemajuan UMKM.

Perbedaan penelitian Kurniawati dengan penelitian ini adalah objek penelitian. Penelitian Kurniawati menggunakan model strategi komunikasi bisnis persuasif (pemberian konsultasi, pelatihan dan pendampingan oleh para ahli), sedangkan penelitian ini menggunakan model pull, push dan pass. Terdapat kesamaan antara implementasi push dan persuasif, meskipun komunikasi persuasif tidak seholistik push, terutama dalam manajemen pesan. Kesamaan lain adalah subjek penelitian, yakni UMKM.

Adapun tujuan penelitian ini adalah ingin mengetahui strategi komunikasi bisnis HIPMIKINDO dalam mensinergikan sumberdaya akademisi dan pelaku UMKM. Hal ini tentu berkaitan dengan positioning HIPMIKINDO di antara pemerintah, UMKM dan akademisi.

\section{METODOLOGI}

Pendekatan penelitian adalah kualitatif. Dalam penelitian ini, analisis data kualitatif dilakukan secara induktif, yaitu tidak dimulai dari deduksi teori tetapi dimulai dari fakta empiris, yakni fenomena UMKM, eksistensi HIPMIKINDO, peran pemerintah dan potensi para akademisi. Peneliti terjun ke lapangan, mempelajari, menganalisis, menafsirkan dan menarik kesimpulan dari fenomena yang ada. Dari data tersebut, peneliti kemudian menganalisis sehingga menemukan makna sebagai hasil penelitian. Tahapan reduksi data sampai pada tahapan kategorisasi data dilakukan berdasarkan kerangka teori strategi pull, push dan pass.

Adapun metode yang digunakan adalah deskriptif, yakni dengan mendeskripsikan pola-pola komunikasi yang terjadi. Dari pola-pola hubungan HIPMIKINDO dengan UMKM dan para akademisi, dibuat deskripsi secara sistematis, faktual, dan akurat tentang faktafakta dan sifat-sifat populasi. Melalui kerangka konseptual (landasan teori strategi pull, push dan pass), peneliti menggambarkan realitas lapangan, sehingga didapatkan gambaran yang detil dari strategi komunikasi bisnis yang terjadi.

Informan dan sumber informasi didapatkan melalui teknik purposive, yakni peneliti melakukan seleksi berdasarkan kapasistas, pengetahuan dan pertimbangan keterkaitan secara langsung dengan strategi komunikasi bisnis HIPMIKINDO. Dari teknik purposive tersebut didapatkan informan kunci antara lain Ketua Umum Hipmikindo, para pejabat HIPMIKINDO Jakarta, Tenaga Pendamping dan para pelaku UMKM Binaan. Adapun informan pendukung adalah Pejabat Operasional Harian Pembinaan UMKM Hipmikindo (2 orang), para pebisnis yang aktif terlibat dalam setiap kegiatan Hipmikindo (2 orang), Tenaga Pendamping UMKM dan juga pelaku usaha binaan Hipmikindo (1 orang), Tenaga Pendamping dari kalangan akademisi murni (2 orang), akademisi yang kampusnya terdapat entrepreneur center (1 orang), Pelaku UMKM yang menjadi anggota binaan (1 orang), Pelaku UMKM bukan anggota binaan tetapi mengetahui Hipmikindo (3 orang). Jadi, total informan terdapat 12 orang. 
Dapat dikatakan bahwa metode purposive tersebut didahului dengan metode rekomendasi atau lebih tepatnya snow ball. Penentuan informan pertama atas rekomendasi informan pertama, tetapi di antara alternatif informan yang direkomendasikan, peneliti masih memilihnya berdasarkan peran dan pertimbangan kompetensi komunikasi, misalnya waktu dan tempat yang dapat peneliti jangkau.

Di lain pihak, sehubungan dengan kondisi pandemi, dapat dikatakan menjadi kekurangan dalam proses penelitian ini, utamanya dalam pencarian informan. Di samping perkantoran sangat tertutup dan selektif serta menerapkan protokol kesehatan yang cukup ketat, suasana kedekatan yang ingin dibangun peneliti cukup sulit terwujud. Penggalian data terbatas pada waktu tertentu sesuai perjanjian, dengan suasana cukup darurat dan kegiatan operasional perbisniasan yang tidak aktif sebagaimana normalnya. Jika pada kondisi normal para narasumber dapat ditemui secara bersama dalam satu waktu, tetapi pada saat pendemi tidak demikian. Narasumber kunci, yakni para pejabat Hipmikindo banyak melakukan komunikasi melalui media sosial, tatap muka langsung hanya penulis dapatkan dengan para UMKM binaan dan non binaan saja.

\section{HASIL DAN PEMBAHASAN}

\section{Strategi Komunikasi Bisnis HIPMIKINDO dalam Menjalin Mitra}

Dalam mensinergikan sumberdaya pelaku UMKM dan para akademisi, HIPMIKINDO membutuhkan sinergi pula dengan mitra lainnya, di antaranya BNSP sebagai langkah institusionalisasi fungsional tenaga akademisi. Artinya, terdapat standarstandar atau sinkronisasi antara konsep dan terapan lapangan yang harus distandarisasi oleh BNSP. Setelah mekanisme standar dilalui, hasil dari proses standarisasi tersebut adalah co-creation antara akademisi dan para pelaku UMKM. Akademisi mengidentifikasi UMKM needs, problems dan alternatif solution. Adapun para pelaku UMKM "menerima" para akademisi sebagai "pendamping". Oleh karena komunikasi bisnis ini tidak mungkin dilakukan secara parsial karena simpul komunikasinya cukup banyak dan terus berkembang, maka HIPMIKINDO dan para akademisi memiliki prakarsa entrepreneur center. Di tempat inilah komunikasi bisnis pada level kelompok sampai komunitas dan organisasi terimplementasi.

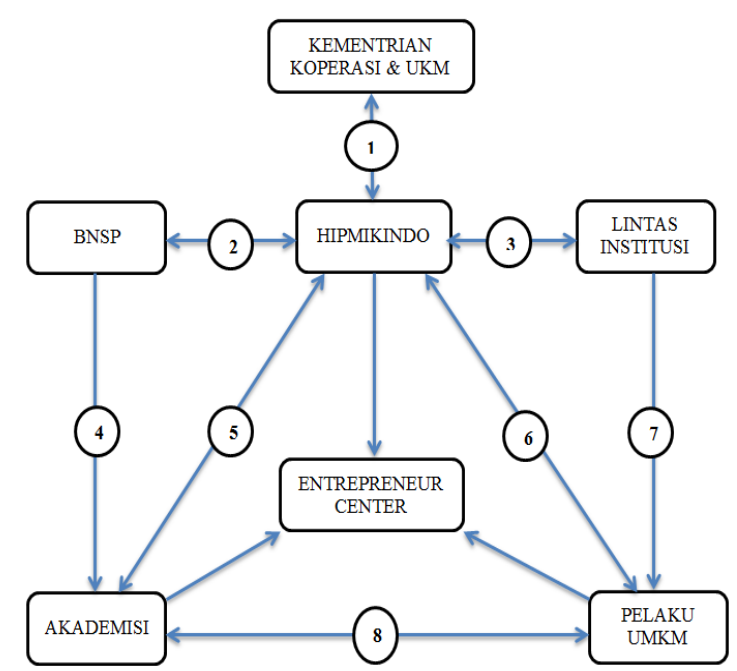

Gambar 2. Mapping Strategi Komunikasi Bisnis Sinergis (diolah peneliti)

Dari Gambar 2, tampak bahwa simpul komunikasi bisnis, sinergi antara pelaku UMKM dan akademisi terselenggara di Entrepreneur Center. Pada titik 1, terlihat komunikasi vertikal antara HIPMIKINDO dan Kementerian Koperasi dan UKM. Di titik 2, tampak bahwa HIPMIKINDO menjalin mitra strategis dengan BNSP dalam rangka menstimulasi akademisi (Poin 4). Pada poin 3, HIPMIKINDO juga bersinergi dengan institusi lain dalam menstimulasi pelaku UMKM (poin 7). Di poin 5, 6 dan 8 tampak bahwa HIPMIKINDO, akademisi dan pelaku UMKM bersinergi pada Entrepreneur Center, yang dapat dinyatakan bahwa Entrepreneur Center merupakan latar/setting terlaksananya sinergi 
komunikasi bisnis antara akademisi dan pelaku UMKM.

\section{Strategi Komunikasi Bisnis HIPMIKINDO Pull secara Vertikal}

Komunikasi bisnis vertikal antara manajemen HIPMIKINDO dan pemerintah dilakukan berdasarkan target luaran sebuah kebijakan kebijakan untuk mendorong UMKM agar terus terfasilitasi kebutuhan, masalah dan solusinya. Beragam stimulus kemudian tersalurkan, baik dari sektor perbankan ataupun non perbankan.

Dalam penjelasan yang lebih rinci, misi HIPMIKINDO adalah menumbuhkan, mengembangkan kemampuan usaha dan meningkatkan kemandirian, keber-samaan, kekeluargaan dalam daya saing dan kewirausahaan pengusaha mikro, kecil dan menengah yang berwawasan lingkungan, keseimbangan kemajuan dan kesatuan ekonomi secara nasional. Konsep wawasan lingkungan akan lahir pula komunikasi bisnis, mengingat isu lingkungan tidak akan terlepas dari muara-muara bisnis. Pada bidang pemasaran, UMKM tentu harus diarahkan pada isu-isu "ramah lingkungan", termasuk "ramah kesehatan", serta "ramah keagamaan". Itu artinya HIPMIKINDO tidak hanya berperan pada sisi ekonomi, tetapi juga mendukung program strategis yang sangat potensial didukung secara nasional, bahkan internasional. Oleh karena itu, tidak berlebihan jika sering menyebutkan diri dalam misi daya saing global. Hal itu juga menandakan bahwa HIPMIKINDO sadar terhadap majunya dunia digital.

Dilihat dari aspek teoritis, maka strategi yang digunakan HIPMIKINDO dominan pada pull. Citra HIPMIKINDO sebagai himpunan yang merepresentasikan harapan kemajuan di kalangan rakyat terbawah sampai pada penyerapan teknologi sebagai upaya peningkatan taraf hidup dan roda perekonomian dapat terkonstruksi secara positif. Hal ini menciptakan formasi misi pemerintah sangat terbantu.
Dari gambaran ini terlihat bahwa posisi pemerintah dalam meningkatkan sumberdaya UMKM sebenarnya memang membuka peran yang lebih besar bagi HIPMIKINDO. HIPMIKINDO tidak hanya berpeluang menjadi sosialisator program pemerintah tetapi juga motivator bagi akademisi. Sedangkan bagi UMKM, di posisi ini Hipmikindo dianggap mampu menjadi pengayom. Dengan demikian, posisi pemerintah secara implisit masih pada konteks birokrat, atau masih dianggap sebagai pembuat kebijakan.

\section{Strategi Komunikasi Bisnis Pull, Push dan Pass HIPMIKINDO dalam Mensinergikan UMKM dan Akademisi}

Langkah sertifikasi para akademisi, memang tidak secara langsung menyelesaikan persoalan capacity building para pengusaha kecil, terlebih lagi persoalan kultur para pengusaha kecil itu sendiri, yang tidak secara langsung menerima proses pendampingan. Persoalan lain adalah kapasitas akademisi yang sebagian besar memang tidak sepenuhnya memiliki pengalaman bisnis di sektor mikro dan kecil ataupun menengah, sehingga menimbulkan citra lain di mata sebagian pengusaha kecil yang didampinginya. Oleh karena itu fenomena pemberdayaan akademisi yang harus bertransformasi menjadi "praktisi" sebagai pendamping UMKM, menghadapi tantangan kolaboratif. Namun demikian, pemenuhan sumberdaya pendamping UMKM dari akademisi ini dianggap HIPMIKINDO paling ekspektatif, paling potensial dan paling akseleratif. Oleh karena itu dibutuhkan langkah legitimasi dan institusionalisasi. Inilah bidang strategis dari BNSP.

Dalam konteks ini, strategi yang digunakan HIPMIKINDO adalah pull dan push dengan memperkuat peran BNSP dalam menyelesaikan kesenjangan trust pelaku UMKM terhadap tenaga pendamping (push). Peran HIPMIKINDO untuk mengakselerasi dan memfasilitasi sertifikasi 
tenaga pendamping UMKM dari kalangan akademisi dapat diterima BNSP sebagai terobosan strategis. Hal ini sekaligus menandakan bahwa HIPMIKINDO dipandang sebagai mitra strategis BNSP (pull).

Pada periode-periode selanjutnya, HIPMIKINDO mengorganisasikan komunikasi bisnis secara lintas institusi. Seetelah HIPMIKKINDO berhasil menarik perhatian para pelaku UMKM ataupun para pendamping UMKM, dengan motivasi start up, maka isu kualitas produk hasil UMKM menjadi target lanjutan. Pada sisi marketing communication, HIPMIKINDO kemudian menggagas betapa pentingnya lebel halal dan standarisasi higienis lainnya, mengingat UMKM binaan banyak didominasi oleh usaha di bidang kuliner.

Di samping strategi pull dengan mengajukan argumentasi HIPMIKINDO sebagai fasilitator, tetapi strategi pass juga dilakukan. Mengingat pemantauan produk olahan makanan akan terus diwarnai kecurigaan terutama terhadap produk usaha mikro dan kecil, yang memang kompetensi higienis menjadi tantangan serius, maka HIPMIKINDO berharap komunikasi terus terjalin antara UMKM - HIPMIKINDO BPOM dalam program yang berkesinambungan. Artinya, harapan HIPMIKINDO sampai pada dicanangkannya upaya - upaya implementatif dalam program pengawasan yang lebih sistematis. Terlebih lagi dalam konteks budaya bisnis kaizen yang menjadi landasan kompetensi bisnis dalam level UMKM, yakni 5S: (Seiri, Seiton, Seiso, Seiketsu dan Shitsuke) yang diadaptasi dalam bahasa Indonesia menjadi 5R: Ringkas, Rapi, Resik, Rawat dan Rajin.

Meskipun HIPMIKINDO memiliki platform yang sangat membumi dengan UMKM, tetapi komunikasi bisnis yang terjalin tidak dengan cepat menemukan makna intersubjektif progresif. Namun demikian, dengan tidak mengurangi esensi pesan dan substansi komunikasi bisnis, HIPMIKINDO melakukan: a) Memberi informasi (informing), b) Membujuk atau persuasi (persuading), c) Melakukan kerjasama atau kolaborasi (collaborating). Pada tahapan informasi (informing), HIPMIKINDO banyak mendengarkan kebutuhan dan aspirasi dari para pelakunya, kemudian ditindaklanjuti dalam rapat manajemen untuk diteruskan pada usulanusulan kepada pemerintah. Meskipun program-program pemerintah tentang peningkatan kapasitas UMKM sudah cukup lengkap, tetapi komunikasi yang dilakukan HIPMIKINDO tidak berlangsung pada jalur atas ke bawah. Segala informasi tentang UMKM dari bawah dikelola kemudian disesuaikan dengan segala kebijakan program pemerintah yang sudah ada, selanjutnya disampaikan pada para pelaku UMKM.

Masalah klasik yang selalu disampaikan oleh UMKM adalah permodalan, maka pihak HIPMIKINDO berusaha memfasilitasi. Jumlah anggota yang sangat potensial akan terus bertambah, menjadi modal dasar bagi HIPMIKINDO untuk meyakin-kan para pemangku kepentingan untuk mempermudah kepengurusan permodalan.

Tahap informasi berikutnya adalah masalah perizinan. Meskipun pihak manajemen sudah banyak memahami berbagai peraturan yang ditetapkan pemerintah, tetapi pihak HIPMIKINDO lebih banyak men-dengarkan terlebih dahulu segala inspirasi pedagang kecil yang ingin mengembangkan usahanya. Solusi pengembangan ini kemudian dianggap HIPMIKINDO menjadi momentum penyampaian kebijakan perizinan, untuk menstimulasi para pedagang agar mampu mengem-bangkan kapasitas pemasaran, misalnya jika akan dikembangkan pada jalur minimarket. Jadi pada tahap ini, HIPMIKINDO banyak melakukan aksi turun ke bawah, menyerap aspirasi kemudian menyampaikan informasiinformasi pengembangan bisnis. Pada tahapan ini, kedekatan HIPMIKINDO 
dengan banyak UMKM terjalin dengan cepat.

Dalam konteks ini, strategi pull, push dan pass terimplementasi. Pull, HIPMIKINDO membangun positioning di tengah pelaku UMKM secara luas. Push, komunikasi bisnis yang sangat motivatif prospektif bagi masa depan UMKM terimplementasi. Selanjutnya strategi pass yang terangkum dalam bahasa pembinaan, pengayoman dan pembangunan kapasitas sumberdaya.

Dalam tahapan membujuk atau persuasi (persuading), HIPMIKINDO terus mempersuasi para pelaku UMKM, baik yang baru bergabung ataupun yang sudah lama, untuk terus meningkatkan kapasitasnya. Ada semacam proses negosiasi dalam tahapan ini. Negosiasi yang dimaksud adalah benefit, bagi UMKM yang melakukan perizinan dan mematuhi proses produksi sesuai arahan HIPMIKINDO, maka banyak benefit yang akan didapatkan, terutama pembinaan yang terus diarahkan pada pengembangan pasar dengan segala kemudahannya.

Pada tahapan inilah timbulnya gagasan HIPMIKINDO untuk memperluas proses pendampingan dengan melibatkan pihak akademisi, sehingga HIPMIKINDO banyak melakukan pendekatan dengan beberapa kampus. Sejalan dengan semakin banyaknya anggota, maka tidak memungkinkan proses pendampingan dapat menjangkau seluruh anggota, sehingga dibuat program-program pendampingan yang melibatkan sumberdaya Perguruan Tinggi. Dari ini pula sertifikasi pendamping UMKM kemudian direspon oleh BNSP. Tampak bahwa strategi push sangat dominan, karena HIPMIKIN-DO berupaya maksimal untuk mengonstruksi persoalan sinergi yang sangat urgen .

Pada tahapan kerjasama atau kolaborasi (collaborating), selain kerjasama dengan pihak Perguruan Tinggi, HIPMIKINDO juga berkolaborasi dengan pihak manapun yang ingin mengembangkan bidang usaha UMKM. Pihak HIPMIKINDO kemudian membuka kesempatan untuk semua kalangan menjadi tenaga pendamping. Sumberdaya ini bisa diikuti oleh pelaku UMKM yang ingin mengembangkan kapasitasnya menjadi trainer. Mengingat banyak juga para sarjana yang terjun dalam UMKM dan merintis serta mengembangkan usaha kemudian ingin berbagi pengalaman, program ini cukup diminati. Di sinilah peran BNSP sangat terbantu.

Program pendampingan juga sangat didukung oleh BPOM, Badan Pengawas Obat dan Makanan. Mengingat standar makanan sampai pada sertifikasi halal menjadi target utama BPOM, profesi pendamping UMKM sangat strategis. HIPMI-KINDO banyak terlibat dalam banyak kegiatan pembekalan, seminar dan workshop. Dengan proses kolaborasi ini, eksistensi Hipmikindo terus didukung pemerintah, terutama dari pihak BNSP, sehingga bidang-bidang lain juga terus dikembangkan. Kolaborasi dengan Perguruan Tinggi terlihat dalam pendirian Entrepreneur Center yang memudahkan Hipmikindo mendapat fasilitas kemudahan dari kampus untuk terus memadukan program-program kolaboratif, baik peningkatan kapasitas pelaku UMKM serta para akademisi yang ingin menekuni profesi trainer UMKM. Adanya Entrepreneur Center akan mempermudah implementasi strategi push dan pass sinergi antara BNSP dan para akademisi. Push dengan terus mendorong akselerasi digitalisasi UMKM dan pass dengan terus membangun sinergi antara BNSP dan para akademisi dalam bentuk sertifikasi ataupun pengembangan fungsional lainnya.

Sosialisasi visi dan misi HIPMIKINDO sebagai strategi pengelolaan pesan dalam implementasi push, antara lain tertera: a) Memperkuat peran usaha miko, kecil dan menengah sebagai dasar perekonomian nasional; b) Mengoptimalkan jejaring dan kemitraan dengan lintas sektor, 
regional maupun international dalam peraturan ekonomi global serta memfasilitasi partisipasi pengusaha mikro, kecil dan menengah Indonesia dalam expo/pameran berskala nasional dan international; c) Mengakselerasi pengembangan usaha mikro, kecil dan menengah ke semua wilayah dalam mendukung ekonomi wilayah yang berdampak positif pada regional development; d) Meningkatkan kompetensi, keterampilan dan produktivitas serta memberikan perlindungan usaha dan advokasi, sehingga terwujud peluang kerja serta menyerap tenaga kerja yang lebih luas; e) Meningkatkan kemandirian, daya saing, kesejahteraan yang berkeadilan dan kemakmuran.

Hal ini menjadi manajemen pengelolaan pesan yang sangat strategis, karena teks: mengoptimalkan jejaring dan kemitraan dengan lintas sektor, regional maupun international dalam peraturan ekonomi global serta memfasilitasi partisipasi pengusaha mikro, kecil dan menengah Indonesia dalam expo/pameran berskala nasional dan international, sangat berkaitan dengan peningkatan dan pengembangan sumberdaya UMKM yang tentunya juga menjadi gambaran masa depan UMKM. Terlebih lagi teks: serta memberikan perlindungan usaha dan advokasi, sehingga terwujud peluang kerja serta menyerap tenaga kerja yang lebih luas, menjadi sisi push strategy yang memang membutuhkan sinergi berkesi-nambungan.

\section{Manajemen Pengelolaan Pesan dalam Strategi Komunikasi Bisnis HIPMIKINDO untuk Mensinergikan Sumberdaya Akademisi dan Pelaku UMKM}

Belum selesai tantangan yang satu, timbul lagi tantangan yang lain, intinya adalah tantangan sumberdaya yang adaptif dan responsif. Bahasan utamanya adalah UMKM lokal. Deklarasi negara Jepang dengan Society 5.0 di satu sisi memberikan motivasi dan harapan positif. Setidaknya kesan ini banyak dipahami oleh para akademisi, namun tidak demikian dengan para praktisi/pelaku UMKM. Konsep 5.0 justru lebih menekankan sumberdaya manusia (SDM) sebagai pusat, sedangkan teknologi hanya sebagai tools. Kata kunci bukan tools, tetapi human, atau intinya tetap pemberdayaan manusia (human-centered).

Dengan demikian, Society 5.0 menjanjikan kehidupan masyarakat di masa depan menjadi lebih baik karena nilai-nilai dan pelayanan yang baru, yang tercipta secara terus menerus dan membuat hidup bertahan lebih lama. Sebenarnya hal ini merupakan kaji panjang negara-negara di seluruh dunia, yakni konsep teknologi yang mampu mengatasi kerapuhan fisik manusia. Pesan positif yang dikonstruksi oleh Society 5.0 membawa optimisme baru, bahwa manusia tetap sebagai pusat peradaban di dunia. Agar fungsi tersebut tidak tereduksi, maka tugas manusia adalah mengendalikan teknologi, agar tidak menjadi objek teknologi. Lingkar permasalahan pada akhirnya tetap kembali pada tuntutan SDM di tengah kemajuan teknologi.

Ketika persoalan SDM menjadi pusat pembicaraan, maka institusi pendidikan tinggi sebagai "rumah" para akademisi menjadi sasaran harapan. Meskipun fokus pengembangan keterampilan, fleksibilitas program studi dalam hal mata kuliah dan disiplin ilmu, keterbukaan dalam inovasi masih menjadi tuntutan dan tantangan yang belum sepenuhnya terjawab, tetapi keberadaan para akademisi tetap menjadi tumpuan, utamanya dalam bidang kewirausahaan berbasis teknologi digital (technopreneurship). Jadi, dalam hal ini push HIPMIKINDO melalui pengelolaan kesan eksternalisasi, dapat menginspirasi kapasitas tenaga pendam-ping dalam urgensitas yang tinggi. Dalam konteks pull, HIPMIKINDO tentu kembali memperkuat positioningnya dalam memfasilitasi pengembangan sumberdaya akademisi. Selanjutnya, pass dalam bentuk proyek 


$\begin{array}{lcr}\text { sinergis yang } & \text { mentransformasikan } \\ \text { entrepreneurship } & \text { ke } & \text { arah } \\ \text { technopreneurship. } & & \end{array}$

Pada proses komunikasi bisnis, tentunya Hipmikindo juga membuat perencanaan pengelolaan pesan. Perencanaan yang akhirnya menjadi strategi yang dimaksud dalam bentuk penyadaran perubahan dan siklus perubahan bisnis.

Seperti halnya hukum alam yang mewaktu, demikian pula siklus bisnis. Diawali dengan rintisan kemudian berkembang, meniti puncak keberhasilan, maka akan sampai juga pada penurunan bahkan kebangkrutan. Hal ini bukan suatu yang berlebihan, tetapi siklus ini dialami oleh siapa saja dan tidak ada penolakan dari pelaku manapun. Hanya saja, persoalan kebangkrutan masih dapat diperdebatkan. Oleh karena bisnis bukan merupakan suatu kepastian, melainkan penuh dengan ketidakpastian, maka dibutuhkan astisipasi. Bangkrut memang tidak akan terjadi jika ada tindakan sebelum bangkrut. Inilah era disrupsi, sebagai tantangan dalam dunia bisnis apapun dan dimanapun.

Tindakan antisipatif inilah yang menjadi salah satu daya tahan bisnis dalam menghadapi perubahan. Perubahan yang seringkali tidak diantisipasi banyak berdampak serius pada waktu tertentu. Adanya pesaing, pembangunan wilayah, kemajuan teknologi, tawaran iklan dan media, gaya hidup dan pergeseran nilai, masuknya budaya-budaya baru hanyalah sebagian kecil perubahan yang sangat berdampak pada kestabilan bisnis. Fenomena ini menjadi narasi perubahan yang menjadi andalan pesan dalam setiap kesempatan sosialisasi program-program HIPMIKINDO.

Narasi ini ternyata diperkuat oleh testimoni banyak pebisnis yang sebagian besar dalam perjalanan rintisannya telah berganti dan berubah bidang bisnis yang digelutinya. Tidak hanya itu, banyak di antara pebisnis yang pada awalnya bekerja di sektor formal. Terdapat pula di antara mereka yang dari awalnya tidak ada rencana untuk menggeluti bisnis tertentu tetapi kemudian tertekan oleh keadaan yang justru membuatnya terbuka untuk melakukan bisnis.

Kesimpulan sementara yang dapat diperoleh dari beberapa analisis kasus audien, HIPMIKINDO menyimpulkan bahwa audien kemudian menyadari bahwa yang abadi bukan keuntungan atau bahkan bisnis itu sendiri, tetapi perubahanlah yang abadi. Bisnis ada sebelum perubahan, tetapi bisnis itu akan tetap bertahan jika mampu mengikuti perubahan. Oleh karena itu, sinergi komunikasi bisnis BPOM dan Pelaku UMKM sudah diimplementasikan secara push, dengan motivasi benefiditas antara dua belah pihak; pull dengan peningkatan peran HIPMIKINDO yang akan terus memfasilitasi upaya BPOM dalam meningkatkan kualitas higienis dengan membangkitkan kemampuan emosional dan spiritual para pelaku UMKM dalam berbisnis. Selanjutnya tentu optimalisasi strategi pass karena menyangkut langkahlangkah yang sustainable.

Pemerintah (birokrat) dan akademisi memang melihat UMKM dalam peta percaturan bisnis yang sangat ketat, mudah berubah dan disruptif. Wacana-wacana ini tentu masih sulit dipahami oleh para pelaku UMKM yang cenderung masih memandang dunia bisnis sebagai kegiatan menjual dan membeli dalam konteks pasar yang tradisional dan konvensional.

Dilihat dari perkembangan teknologi yang terus-menerus sebenarnya terdapat hal positif. Mereka, para pelaku usaha yang proaktif memanfaatkan teknologi, maka keberadaan teknologi menjadi peluang strategis, namun bagi mereka yang menganggap teknologi sebagai tambahan beban, maka akan membuat teknologi sebagai ancaman. Harapan pemerintah dengan kolaborasi, bersama HIPMIKINDO dan akademisi, dapat mengarahkan UMKM pada pengelolaan bisnis yang inovatif teknologis. Hal ini terkesan berlebihan, 
tetapi tidak ada pilihan yang dirasakan pemerintah, bahwa persoalan ini adalah tuntutan yang tidak dapat dihindarkan.

Pemerintah yang berusaha mensosialisasikan tantangan Industri 4.0 banyak mengalami hambatan komunikasi. Secara tidak langsung, isu Revolusi Industri 4.0, mengundang tantangan kepada UMKM tentang adanya dua makna, yaitu disrupsi dan kreasi. Makna disrupsi (dalam konteks ini), menjadikan pola tatanan lama menjadi usang, karena peran manusia digantikan oleh teknologi yang canggih. Demikian pula dalam bidang usaha, maka pengusaha yang terdepan dalam memanfaatkan teknologi, akan terdepan pula dalam memanfaatkan peluang. Sedangkan makna kreasi (dalam konteks ini), adalah tantangan positif yang akan memacu manusia untuk dapat menciptakan berbagai peluang usaha berbasis teknologi digital, atau istilah barunya sebagai technopreneur. Hal-hal baru ini masih dianggap beban bagi UMKM.

HIPMIKINDO, sebagai manaje-men yang memberdayakan pengusaha mikro, kecil dan menengah dalam rangka memenuhi tuntutan pertumbuhan ekonomi mikro nasional, menyadari begitu pentingnya sumber daya manusia. HIPMIKINDO memandang kerjasama dengan lembaga pendidikan tinggi menjadi hal paling strategis. Jika HIPMIKINDO menginginkan pelaku usaha binaannya tetap kompetitif dan memiliki keunggulan dalam bersaing maka pemberdayaan sumber daya akademisi menjadi pilihan paling rasional.

Demikian banyaknya pengusaha kecil yang masih perlu peningkatan kapabilitas, baik dalam hal pengetahuan (knowledge) maupun keahlian dan keterampilan (skill) maka cara pandang dan pendekatan konvensional berupa training, persuasi ataupun workshop tidak lagi memadai. HIPMIKINDO sudah melakukan hal-hal tersebut, tetapi efek perbaikan atau perubahan yang signifikan, belum memuaskan. Sebagai hasilnya, mereka memberdayakan sumberdaya akademisi sebagai pendamping pelaku usaha kecil (UKM). Para pendamping ini diberikan pembekalan standar sebagai trainer, leader dan entrepreuner, yang kompetensinya berakhir pada kualifikasi sertifikasi. Dalam hal ini HIPMIKINDO melibatkan BNSP (Badan Nasional Sertifikasi Profesi) sebagai pihak penguji, yang berwenang memberikan sertifikasi, demi standar pendamping seperti yang dikehendaki manajemen HIPMIKINDO.

Proaktif HIPMIKINDO kemudian mendorong didirikannya entrepreneur centers sebagai hasil kolaborasi dan elaborasi komunikasi bisnis dengan para akademisi. Jika dikatakan dalam bahasa sinergis, maka eksistensi HIPMIKINDO berada pada sentral triple helix, yakni berada pada simpul 3 sudut: Pemerintah, UMKM dan akademisi. Semakin tampak bahwa HIPMIKINDO justru memiliki posisi kunci dari proses sosialisasi bisnis. Komponen akademisi, yang dirasakan lebih mampu memahami arah pembangunan bisnis, kajian sumberdaya manusia, manajemen disrupsi dan perubahan, serta implementasi teknologi menjadi kelengkapan berurgensitas tinggi.

Dengan demikian, implementasi strategi push, terimplementasi dalam: a) Pesan perubahan. Titik fokusnya adalah "mengeluarkan" sudut pandang atau pemikiran para pelaku UMKM yang dirasakan masih sempit, yakni terjualnya produk atau komoditas, tanpa mempertimbangkan "ancaman" terhadap situasi dan kondisi comfort zone yang dijalankan; b) Pengelolaan pesan siklus S yang menjadi keniscayaan dalam berbagai bidang kehidupan, terutama bisnis. Pesan ini cukup dikenal sebagai pesan sigmoid yang berintikan tiga hal: pertama, semua bisnis pasti mengalami siklus rintisan, kemajuan dan penurunan; bisa secara cepat ataupun lambat, dan ini menimpa bidang bisnis apapun. Kedua, sebelum mengalami penurunan dari puncak $\mathrm{S}$ yang dimaksud, maka harus ada terobosan, antara lain berupa inovasi dan kreativitas agar ada penyegaran 
bisnis untuk menaikkan kembali gairah konsumen. Ketiga, inovasi dan kreativitas harus dilakukan menjelang puncak atau setidaknya pada puncak keberhasilan usaha, dan jika terlambat maka akan semakin berat menghadapi recovery puncak keberhasilan yang lama.

Proaktif HIPMIKINDO kemudian mendorong didirikannya entrepreneur centers sebagai hasil kolaborasi dan elaborasi komunikasi bisnis dengan para akademisi. Jika dikatakan dalam bahasa sinergis, maka eksistensi HIPMIKINDO berada pada sentral triple helix, yakni berada pada simpul 3 sudut: Pemerintah, UMKM dan akademisi. Semakin tampak bahwa Hipmikindo justru memiliki posisi kunci dari proses sosialisasi bisnis. Komponen akademisi, yang dirasakan lebih mampu memahami arah pembangunan bisnis, kajian sumberdaya manusia, manajemen disrupsi dan perubahan, serta implementasi teknologi menjadi kelengkapan berurgensitas tinggi.

\section{SIMPULAN}

Berdasarkan hasil penelitian dan pembahasan yang telah peneliti kemukakan, strategi komunikasi bisnis HIPMIKINDO dalam mensinergikan sumberdaya pelaku UMKM dan para akademisi, secara konsep dapat dijelaskan dalam terminologi push, pull dan pass. Pada tahapan awal sejak HIPMIKINDO berdiri sampai dengan menjelang maraknya penggunaan media baru dalam bidang pemasaran, maka strategi komunikasi bisnis yang digunakan adalah model pull. Model ini difokuskan pada pengembangan kapasitas usaha UMKM sekaligus peningkatan sumberdaya UMKM, meskipun dari sisi teknis, unsur tantangan dan tuntutan teknologi belum menjadi target peningkatan kapasitas sumberdaya manusia secara langsung.

Sejak tuntutan dan tantangan daya saing tidak terhindarkan lagi, diperkuat oleh fenomena-fenomena disrupsi bisnis di berbagai lapisan, terutama di lapisan bisnis berskala besar, strategi komunikasi bisnis push digunakan sebagai upaya peningkatan sumberdaya pelaku UMKM secara langsung. Maksud secara langsung adalah target inovasi dan kreativitas bisnis bagi pelaku UMKM, yang sebelumnya hanya ditargetkan pada peningkatan kemampuan kuantitas komoditi yang dihasilkan. Strategi push ini juga menjadi inspirasi HIPMIKINDO dalam memperluas mitra pembinaan UMKM, karena tuntutan daya saing yang tidak lagi dapat dihindari, akibat penggunaan internet yang tidak terbatas dan tidak dapat dibatasi.

Strategi pengelolaan pesan pada tahapan implementasi komunikasi bisnis pull, HIPMIKINDO menampung semua aspirasi dan inspirasi para pelaku UMKM untuk dicarikan jalan keluar pengembangannya. Hasil field research HIPMIKINDO disampaikan kepada pemerintah, selanjutnya feedback dari pemerintah berupa stimulus dan insentif disampaikan kembali kepada para pelaku UMKM. Dalam implementasinya, HIPMIKINDO melegitimasi dirinya sebagai wadah untuk mencapai tujuan bersama yang sangat strategis. Akhirnya terwujud institusionalisasi berupa anggota-anggota binaan.

Strategi pengelolaan pesan pada tahapan implementasi komunikasi bisnis push berbeda dengan tahapan pull. Mengikuti maraknya informasi dan isu bisnis yang diliputi oleh perubahan dan disrupsi, maka HIPMIKINDO membuat manajemen pesan yang dirujuk pada praktikpraktik bisnis modern yang diselenggarakan oleh berbagai korporat. Titik temu inilah yang kemudian berkorelasi pada sisi akademisi. Tantangan sinergitas, pengembangan sumberdaya manusia, peningkatan bisnis dan taraf hidup serta kompetensi UMKM dibutuhkan push, pull dan pass oleh para akademisi terhadap para pelaku UMKM. Simpul komunikasi strategi ini sudah terimplementasi dalam bangunan entrepreneur center.

\section{DAFTAR PUSTAKA}


Afriaris, S., \& Windartini, S. (2021). Model Pengembangan Strategi Komunikasi Bisnis untuk Mencapai Tujuan Pemasaran pada Usaha Kecil Menengah (Studi Kasus Pada Konsep Usaha Rumah Tangga Kerak Nasi). Jurnal EKOBISTEK, 9(1), 12-20. https://docplayer.info/203230620Jurnal-ekobistek-vol-9-no-1-april2020-hal-issn-e-issn-by-lppm-upiyptk-padang.html

Andriani, N. (2020). Strategi Komunikasi Bisnis Mini Market Islam sebagai Pendidikan Kemandirian Santri. Jurnal Al-Hikmah: Ilmu Dakwah dan Pengembangan Masyarakat, 18(2). https://doi.org/10.35719/alhikmah.v18 i2.32

Krisnayana, R. (2016). Peran Komunikasi Bisnis dalam Strategi Bisnis. Dialektika, 3(1). ISSN-e 2654-5985. http://journal.unla.ac.id/index.php/dial ektika/article/view/290

Kurniawati, L. (2021). Strategi Digital Marketing dan Komunikasi Bisnis untuk Enterpreneur Pemula di Indonesia. Sang Pencerah: Jurnal Ilmiah Universitas Muhammadiyah Buton, E-ISSN: 2655-2906, P-ISSN: 2460-5697 7(3), 371-391. https://doi.org/ 10. 35326/pencerah.v7i3.1291

Mellyan, M. (2020). Social Media Marketing; Strategi Komunikasi Bisnis Era Digital (Studi Analisis Portal TaniFund.com). At-Tanzir: Jurnal Ilmiah Prodi Komunikasi Penyiaran Islam, 11(1). ISSN:2085-255X. https://doi.org/10.47498/tanzir.v11i1.3 50

Murdaniati, K., \& Widodo, H. P. (2018). Strategi Marketing Public Relations Matos Mall Dalam Menjaga Mitra Bisnis. JISIP: Jurnal Ilmu Sosial Dan Ilmu Politik, 7(1). ISSN. 2442-6962.

Ningsih, A., Muhyiddin, A., \& Rosyidi, I. (2018). Strategi Komunikasi Bisnis
Kewirausahaan Eco Pesantren Daarut Tauhid. Prophetica: Scientific and Research Journal of Islamic Communication and Broadcasting, 4(1). https://doi.org/10.15575/prophetica.v4i1.2230

Philipus, N. (2018). Komunikasi Bisnis Yang Etis: Sebuah Tinjauan Kritis. Jurnal Komunikasi Dan Bisnis, 6(2). https://jurnal.kwikkiangie.ac.id/index. php/JKB/article/view/570. ISSN: 2355 - 5181.

Phalipi, Shahnan. (2014). Anggaran Dasar Anggaran. Kman V, 1-28. Jakarta: M. P. M. Pusat.

Shansis, Y. T., \& Ratna, V. (2019). Strategi Komunikasi Bisnis dalam Meningkatkan Penjualan Produk Vivelle di Shan Hair Beauty Care. Sinteks: Jurnal Teknik, 8(1). https:// jurnal.stt.web.id/index.php/Teknik/arti cle/view/114

Sitinah, S., \& Sofiawati, S. (2021). Strategi Komunikasi Bisnis Quadro Helix dalam Digitalisasi UMKM Jabodetabek. Komunikata57, 2(1). https://ejournal-

ibik57.ac.id/index.php/komunikata57/a rticle/view/238

Sukma, A. H., \& Pranawukir, I. (2020). Perencanaan dan Strategi Komunikasi Jaringan Franchise Warung Tegal Kharisma Bahari. WACANA: Jurnal Ilmiah Ilmu Komunikasi, 19(2,) 274284.

https://doi.org/10.32509/.v19i2.1159

Suyani, E., Zahara, E., \& Alfiansyah Siregar, F. (2019). Strategi Komunikasi Bisnis Dalam Menerapkan Program Corporate Social Responsibility (Studi Di PT. Coca Cola Bottling Indonesia Cabang Medan). Jurnal Warta Edisi: 59, 13(1). ISSN: 1829-7463. https://jurnal.dharmawangsa.ac.id/ind ex.php/juwarta/article/view/347/340

Widuhung, S. M. (2021). Strategi Marketing 
Public Relations Petromindo Group di Era Pandemi Covid-19. Jurnal Public Relations, 2(1). April 2021. http://jurnal.

bsi.ac.id/index.php/jpr/article/view/30 8
Wijaya, I. S. (2015). Perencanaan dan Strategi Komunikasi. Lentera, Vol. XVIII no. (1). Juni 2015. https://journal.uinsi.ac.id/index.php/le ntera_journal/article/view/428). 